\title{
Woorden maken werelden (en cijfers ook): hoe hoog is nu het percentage veroordeelde outlawbikers?
}

\author{
Arjan Blokland
}

In ons rapport "Profielen van outlaw bikers and outlawbiker clubs" (Blokland e.a. 2017a) concludeerden we dat 'Nederlandse OMG-leden disproportioneel vaak in aanraking zijn gekomen met politie en justitie.' Tijdens de inhoudelijke behandeling van het door het OM ingediende verzoek om de Hells Angels door de civiele rechter verboden te laten verklaren, trekt de advocaat van de Hells Angels - na een methodologisch expert te hebben geraadpleegd - deze conclusie in twijfel op basis van mogelijke type 2 en type 1 fouten gemaakt bij het samenstellen van de steekproef voor ons onderzoek op basis van politiegegevens. In deze bijdrage berekenen we het percentage veroordeelde Hells Angels onder verschillende niveaus van mogelijke vertekening door dergelijke fouten. Op basis van deze scenario's concluderen we dat een realistische schatting van het percentage veroordeelde leden van de Nederlandse Hells Angels ligt tussen 58-96\%; minimaal bijna het dubbele van het percentage in een leeftijd gematchte vergelijkingsgroep van mannelijke motorrijders die geen lid zijn van een outlawmotorclub.

\section{Achtergrond}

In december 2017 verschijnt het eindrapport 'Profielen van Nederlandse outlawbikers en Nederlandse outlawbikerclubs' van een door Politie \& Wetenschap mogelijk gemaakte studie naar de geregistreerde criminele carrières van de leden van Nederlandse outlawmotorclubs en hun officiële supportclubs. In hoofdstuk 5 van dit rapport wordt op basis van de geregistreerde criminele carrières van 1.617 leden van dertien verschillende Nederlandse outlawmotorclubs, waaronder de Hells Angels, een beeld geschetst van de mate waarin leden van deze outlawmotorclubs betrokken zijn bij (georganiseerde) criminaliteit. Een van de belangrijkste conclusies uit het rapport is dat 'Nederlandse OMG-leden disproportioneel vaak in aanraking zijn gekomen met politie en justitie' (Blokland e.a., 2017a, 10)..$^{1}$

1 Het rapport spreekt van OMGs, oftewel outlaw motorcycle gangs. Dit is de term die door de Nederlandse politie en justitie, maar ook in de internationale onderzoeksliteratuur wordt gebruikt. Het gebruik van het woord 'gang' is ongelukkig, niet alleen vanwege de stereotiepe beelden die deze term oproept, maar ook omdat de mate waarin afzonderlijke outlawmotorclubs eventueel aan te merken zijn als 'gangs' nu juist punt van discussie en onderzoek is (Roks \& Van Ruitenburg, 2018). 
Op 29 mei 2018 dient het Openbaar Ministerie een verzoek in bij de Rechtbank Midden-Nederland om Hells Angels MC op grond van artikel 2:20 van het Burgerlijk Wetboek (BW) te laten verbieden. ${ }^{2}$ Op 6 maart 2019 start de inhoudelijke behandeling van de aanvraag van het civiele verbod op de Nederlandse Hells Angels. Belangrijkste vragen die de rechter moet beantwoorden, is of hij van mening is dat (a) de Hells Angels een vereniging vormen in de zin van artikel 2:20 BW, en zo ja, (b) of de werkzaamheid van deze vereniging in strijd is met de openbare orde. Voor die tweede vraag is ook de door de leden gepleegde criminaliteit relevant.

In de voorbereiding van de door hen te voeren verdediging in de zaak omtrent het civiele verbod hebben de advocaten van de Hells Angels een externe expert - professor Peter van der Heijden, hoogleraar Statistiek ten behoeve van de Sociale Wetenschappen aan de Universiteit Utrecht - gevraagd de resultaten uit het rapport, voor zover van toepassing op de Hells Angels, - kort gezegd - kritisch tegen het licht te houden en na te gaan of er, en zo ja welke, kanttekeningen te plaatsen zijn bij het in hoofdstuk 5 geschetste beeld van de Nederlandse Hells Angels. In januari 2019 rapporteert Van der Heijden zijn bevindingen in een brief aan de betreffende advocaten.

Het commentaar van Van der Heijden laat zich samenvatten in drie hoofdpunten:

- De steekproef waarop het onderzoek is gebaseerd, onderschat mogelijk de totale ledenpopulatie van outlawbikerclubs, waardoor de steekproef criminaliteit in de populatie mogelijk overschat.

- De steekproef overschat mogelijk het aantal leden van de Hells Angels, waardoor de steekproef criminaliteit in de ledenpopulatie van de Hells Angels mogelijk overschat.

- Het rapport biedt te weinig informatie om na te kunnen gaan of de plaatsing van de Hells Angels aan de 'bende'-kant van het door Barker (2015; 2017) voorgestelde club-bendecontinuüm terecht is.

Dit commentaar raakt aan de bredere discussie over het nut en de gevaren van het bijhouden van 'gangdatabases' en doelgroepenbestanden in algemene zin en is daarmee ons inziens niet alleen relevant voor onderzoek naar outlawbikers, maar voor al het criminologisch onderzoek dat gebruik maakt van administratieve data. Hierna schetsen we in hoofdlijnen de algemene discussie rondom het gebruik van gangdatabases en geven we een korte samenvatting van de inhoud van het betreffende outlawbikeronderzoek. Daarna volgt puntsgewijs het belangrijkste door Van der Heijden gegeven commentaar en, in reactie hierop, een weging van de mogelijke gevolgen voor de in het onderzoek getrokken conclusies.

2 De aanvraag van een civiel verbod op de Hells Angels past binnen de huidige OM-aanpak van outlawmotorclubs en volgt op eerdere civiele verboden in eerste aanleg van de Bandidos MC (20 december 2017) - waarvan de reikwijdte werd ingeperkt in hoger beroep (18 december 2018) -, Satudarah MC (18 juni 2018) en No Surrender MC (7 juni 2019). Eerder werd ook Broederschap Catervarius door de civiele rechter verboden (17 januari 2018). Meest recent is voor Caloh Wagoh MC een verzoek tot het opleggen van een civiel verbod ingediend (1 augustus 2019). 


\section{Gangdatabases}

Het gebruik van gangdatabases is al lange tijd onderwerp van onderzoek en debat, met name in Amerika, waar men probeert er geweld en overlast door 'straatbendes' mee terug te dringen. Het belangrijkste voordeel van dergelijke databases is de aandacht die hiermee gecreëerd wordt voor groepen die het meeste risico lopen zich in te laten met (zware) criminaliteit. Barrows en Huff (2009) schetsen in Criminology \& Public Policy de belangrijkste bezwaren die kleven aan het bijhouden en gebruik van gangdatabases. Allereerst zijn er bezwaren die samenhangen met zogenaamde type 1-fouten, gevallen waarin een niet-bendelid onterecht geïdentificeerd wordt als lid. Personen die ten onrechte in een gangdatabase terechtkomen, kunnen te maken krijgen met verhoogde politieaandacht, zwaardere sancties en negatieve consequenties op het gebied van school, werk of bijvoorbeeld het verkrijgen van vergunningen. Type 1 -fouten kunnen leiden tot een overschatting van de omvang van de totale ledenpopulatie, maar tegelijkertijd ook tot een onderschatting van de criminaliteit onder daadwerkelijke bendeleden wanneer onterecht als lid aangemerkte personen minder dan daadwerkelijke leden met politie en justitie in aanmerking komen.

Ook type 2-fouten, gevallen waarin een lid ten onrechte niet als zodanig wordt geïdentificeerd, hebben negatieve consequenties. Potentieel gevaarlijke personen krijgen hierdoor mogelijk te weinig aandacht van de politie, ontvangen niet de juiste sancties, of worden uitgesloten van de juiste ondersteuning, bijvoorbeeld deelname aan programma's gericht op het verlaten van bendes. Wanneer bepaalde leden vanwege bijvoorbeeld hun jonge leeftijd, korte lidmaatschapsduur of het niet vertonen van strafbaar gedrag een grote(re) kans lopen door de politie te worden gemist, kan dit eveneens leiden tot vertekening van zowel de omvang als de ernst van het bendeprobleem.

Het eerste punt van commentaar van Van der Heijden behelst de mogelijke gevolgen van type 2-fouten in het samenstellen van de steekproef van ons onderzoek naar de criminele carrières van Nederlandse outlawbikers. Het tweede punt van commentaar betreft de mogelijkheid en gevolgen van type 1-fouten.

\section{Het onderzoek}

Het commentaar raakt het hele onderzoek, maar richt zich met name op hoofdstuk 5 van het genoemde onderzoeksrapport. Dit hoofdstuk beantwoordt de volgende onderzoeksvragen:

- In welke mate zijn leden van verschillende Nederlandse outlawmotorclubs, blijkens hun veroordelingsgeschiedenis, betrokken bij verschillende vormen van criminaliteit?

- Hoe zijn Nederlandse outlawmotorclubs te plaatsen langs het door Barker (2015) voorgestelde club-bendecontinuüm?

Om deze vragen te kunnen beantwoorden wordt gebruik gemaakt van een door de politie aangeleverd bestand met daarin 1.617 bij de politie bekende leden van 
Nederlandse outlawmotorclubs. Deze 1.617 personen zijn door politieambtenaren tussen 2010 en 2015 geregistreerd als lid van een outlawmotorclub in het bedrijfsprocessensysteem van de Nederlandse politie. Lidmaatschap werd afgeleid uit bijvoorbeeld het dragen van het voor outlawmotorclubleden kenmerkende mouwloze vest met daarop het logo van de club, het zichtbaar dragen van clubtatoeages of het frequenteren van besloten clubavonden. Specifieke aanleiding voor de waarneming en registratie kan zowel een verdenking van een strafbaar feit zijn alsook voortkomen uit algemeen controlerend politiehandelen, zoals bijvoorbeeld een grootschalige alcoholcontrole.

Van deze 1.617 personen is de geregistreerde criminele carrière in kaart gebracht op basis van gegevens uit de Onderzoek- en Beleidsdatabase Justitiële Documentatie (OBJD). Registraties in de OBJD hebben betrekking op alle Nederlandse justitiecontacten van de betreffende persoon, maar voor dit onderzoek zijn enkel zaken die eindigden in een schuldigverklaring door een rechter, OM-transactie of beleidssepot meegenomen en gegroepeerd onder de term 'veroordeling'. Vrijspraken, ontslagen van rechtsvervolging en technische sepots blijven derhalve buiten beschouwing. De OBJD registreert de laatst bekende uitspraak, dus ook zaken die pas in hoger beroep in een vrijspraak zijn geëindigd, worden niet als 'veroordeling' aangemerkt. Deze gegevens met betrekking tot de geregistreerde criminele geschiedenis van Nederlandse outlawmotorclubleden zijn vervolgens gebruikt om uitspraken te doen op het niveau van de afzonderlijke clubs.

Van de 319 Hells Angels in de steekproef bleek 81 procent ten minste eenmaal te zijn 'veroordeeld'. Gemiddeld werden leden van de Hells Angels over de totale duur van hun criminele carrière (vanaf de leeftijd van 12 jaar tot en met het jaar 2015) 8,9 keer veroordeeld. Veroordelingen voor afpersing, vrijheidsberoving, mensenhandel, witwassen, overtredingen van de Opiumwet en overtredingen van de Wet wapens en munitie werden apart beschouwd, omdat zij indicatief werden geacht voor 'zwaardere' en meer 'georganiseerde' vormen van criminaliteit. ${ }^{3}$ Van de 319 Hells Angels in de steekproef bleek 8,5 procent ten minste eenmaal te zijn veroordeeld voor een dergelijk delict (percentage niet genoemd in het rapport). Gemiddeld werden leden van de Hells Angels over de totale duur van hun criminele carrière 1,4 keer veroordeeld voor een dergelijk delict (gemiddelde niet genoemd in het rapport).

In hoeverre zijn outlawmotorclubs nu te beschouwen als 'criminele organisaties'? Deze vraag blijkt niet eenvoudig te beantwoorden, niet in de laatste plaats omdat onduidelijk is wat precies wordt bedoeld met deze term. Von Lampe (2016) maakt in zijn boek onderscheid tussen criminele netwerken, verenigingen van criminelen en criminele ondernemingen. Verenigingen van criminelen onderscheiden zich van criminele netwerken door een zekere graad van formalisatie (het vastleggen van procedures om eenheid en zekerheid te scheppen voor de betrokkenen), met name waar het gaat om lidmaatschap. Van een criminele onderneming is sprake voor zover sociale relaties gericht zijn op economische activiteit. Wanneer

3 Over de precieze definitie van 'georganiseerde' misdaad bestaat geen consensus (Finckenauer, 2005). 
leden van een vereniging van criminelen zich gezamenlijk (en met een winstoogmerk) schuldig maken aan crimineel gedrag, kan een vereniging van criminelen echter tegelijkertijd ook een criminele onderneming zijn (Von Lampe, 2016, 182). Barker $(2015$; 2017) stelt voor om outlawmotorclubs te rangordenen op basis van de betrokkenheid van zowel leiders als leden van de betreffende club op een continuüm dat loopt van 'club', via 'vereniging van criminelen' tot 'bende'. Hij redeneert dat wanneer veel clubleden zich schuldig maken aan crimineel gedrag, dit duidt op een klimaat waarin criminaliteit op zijn minst wordt gedoogd en op zijn slechtst wordt gepropageerd. Clubbijeenkomsten zouden dan kunnen functioneren als 'offender convergence settings', plaatsen waar criminelen elkaar treffen, informatie uitwisselen en criminele plannen maken. Wanneer bovendien een groot deel van de leiders van de betreffende club zich schuldig maakt aan crimineel gedrag, vormt dit, aldus Barker, een extra indicatie dat criminaliteit door de leiding niet wordt afgekeurd en wellicht zelfs wordt aangemoedigd. Barker stelt dat wanneer zowel clubleden als clubleiders zich in hoge mate schuldig maken aan zware en georganiseerde criminaliteit, dit een belangrijke aanwijzing is dat de betreffende club te kenschetsen is als 'bende'. Barker noemt overigens geen harde criteria (hoe hoog is 'in hoge mate' precies?) waarop verenigingen van criminelen volgens hem kunnen worden onderscheiden van 'bendes'.

In figuur 1 op p. 251 is de rangordening van de dertien in het onderzoek betrokken Nederlandse outlawmotorclubs op Barkers club-bendecontinuüm weergegeven, waarbij 'mate van betrokkenheid bij georganiseerde criminaliteit' is geoperationaliseerd als het gemiddeld aantal veroordelingen voor dit type criminaliteit. ${ }^{4}$ Onder 'leiders' worden verstaan: presidenten, vicepresidenten, treasurers, sergeants at arms, road captains en nomads.

\section{Het commentaar}

\section{Type 2-fouten: leden niet als zodanig geïdentificeerd}

Het eerste door Van der Heijden genoemde commentaar betreft de representativiteit van de steekproef, of liever gezegd het mogelijke gebrek hieraan. Een steekproef is representatief wanneer alle leden van de totale te onderzoeken populatie - hier alle leden van Nederlandse outlawmotorclubs - een gelijke kans hebben om in de steekproef te eindigen, oftewel wanneer er sprake is van een willekeurige steekproef. Duidelijk is dat in het onderzoek naar leden van outlawmotorclubs geen sprake is van een bewust willekeurige steekproef; de registraties in het bedrijfsprocessensysteem die aan de steekproef ten grondslag liggen, zijn immers niet met dit doel verzameld. Hierdoor is het denkbaar en wellicht zelfs aannemelijk dat leden van outlawmotorclubs die crimineel gedrag vertonen een grotere kans hebben om in de steekproef te eindigen dan leden die geen crimineel gedrag

4 Dit gemiddelde combineert informatie over het percentage leden en leiders dat ten minste één keer is veroordeeld en het aantal keer dat veroordeelde leden en leiders zijn veroordeeld voor georganiseerde criminaliteit. Vanwege privacyoverwegingen is gekozen niet te werken met het percentage veroordeelde leden/leiders. Zie hiervoor p. 99-100 van het rapport. 


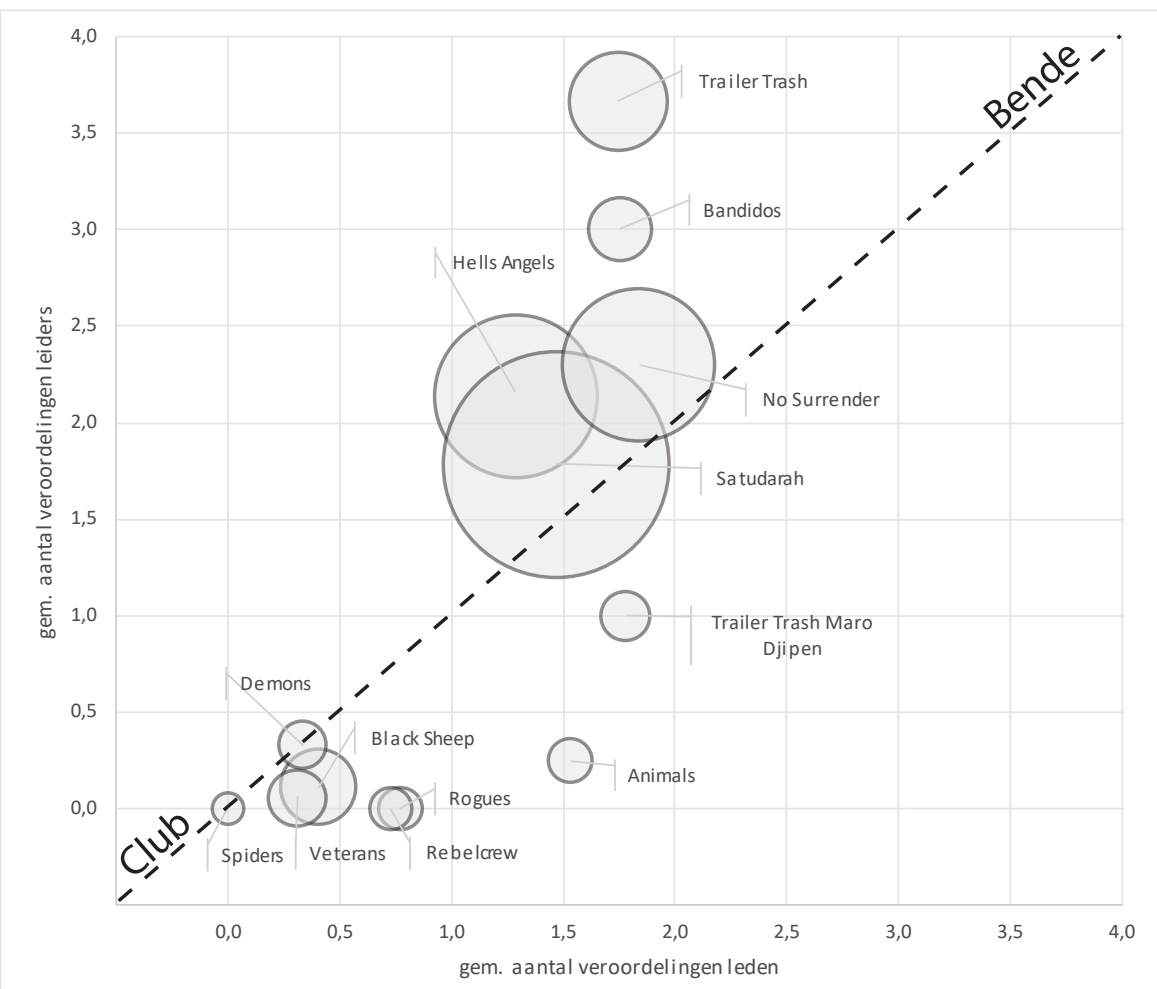

Figuur 1 Rangordening van Nederlandse outlawmotorclubs op Barkers clubbendecontinuüm, assen geoperationaliseerd als het gemiddeld aantal veroordelingen voor georganiseerde criminaliteit voor leden ( $x$-as) en leiders ( $y$-as) van Nederlandse outlawmotorclubs. Diameter van de cirkel relatief aan het aantal leden van de betreffende club in de steekproef.

vertonen. De onderzoeksresultaten zouden dan meer criminaliteit onder leden van outlawmotorclubs laten zien dan daadwerkelijk het geval is. Overigens kan het tegenovergestelde - dat leden die strafbare feiten plegen juist minder kans hebben om geregistreerd te raken, bijvoorbeeld omdat zij hun gedrag actief afschermen van politietoezicht - evenmin worden uitgesloten. In dat geval zouden de onderzoeksresultaten wellicht een te flatteus beeld van Nederlandse outlawbikers schetsen. Meer algemeen bestaat de mogelijkheid dat type 2-fouten bij het samenstellen van de steekproef de prevalentieschatting hebben vertekend. Wanneer de omvang van de gebruikte steekproef de omvang van de totale populatie begint te benaderen, vormt de niet-willekeurigheid van de steekproef echter 
steeds minder een probleem; de mogelijke vertekening betreft dan immers een steeds kleiner gedeelte van de steekproef. ${ }^{5}$

Het totale aantal leden van Nederlandse outlawbikerclubs, en dus ook het totale aantal leden van de Hells Angels, is onbekend (zie echter het tweede punt van het commentaar hierna). In de (buitenlandse) literatuur wordt gesteld dat een chapter (lokale afdeling) van een outlaw motorcycle club minimaal zes en maximaal 25 leden kent. Op basis van het aantal in 2015 bekende chapters schatten we daarom het totale ledenbestand van Nederlandse outlaw motorcycle clubs ergens tussen de 888 en 3.700. Het geschatte aantal leden van de Hells Angels ligt - op basis van het in juni 2016 bekende totaal van achttien chapters - tussen de 108 en 450 . Met 319 leden van de Hells Angels in de steekproef lijkt derhalve ten minste 71 procent van de totale ledenpopulatie van de Hells Angels gedekt - een percentage dat verder oploopt naargelang een gemiddeld Hells Angels-chapter minder dan 25 leden heeft. In hun kennisdocument uit 2014 citeert de Landelijke Eenheid echter een Nederlandse expert die de maximale omvang van een outlawmotorclub-chapter schat op zo'n 40 personen. In dat geval zou de bovengrens van het aantal Nederlandse outlawmotorclubleden op $5.920^{6}$ liggen en dat van de Hells Angels op 720 - de steekproef zou dan nog niet de helft van het daadwerkelijke aantal Hells Angels beslaan.

Wat zijn de mogelijke gevolgen voor de gerapporteerde mate van betrokkenheid van Nederlandse outlawmotorclubleden in het algemeen en die van leden van de Nederlandse Hells Angels in het bijzonder? Van de 1.617 outlawmotorclubleden in de steekproef blijken er 1.387 ooit te zijn veroordeeld; dit is 85,8 procent van de steekproef. Stel nu dat de daadwerkelijke omvang van de ledenpopulatie 5.920 is en stel verder dat van de leden die niet in de steekproef zijn opgenomen, niemand ooit is veroordeeld. In dat geval zou het daadwerkelijke percentage outlawbikers met een strafblad in de populatie slechts 23,4 procent bedragen. Specifiek voor de Hells Angels zou het gerapporteerde percentage van 81 procent, oftewel 260 van de 319 leden in de steekproef, zo laag kunnen zijn als 36,1 procent. ${ }^{7}$

Op twee punten valt naar onze mening wel iets af te dingen op dit, ook volgens Van der Heijden zelf trouwens, extreme scenario. Ten eerste gaat een populatieschatting van 5.920 ervan uit dat alle Nederlandse outlawmotorclub-chapters een omvang hebben van 40. Dit lijkt zeer onwaarschijnlijk. Voor zover er al sprake is van dergelijke grote chapters, lijken zij eerder uitzondering dan regel. Verder gaat

$5 \quad$ Een voorbeeld ter verduidelijking: stel een vaas bevat vijf rode en vijf gele knikkers. De verdeling in de populatie is derhalve 50-50. Bij maximale vertekening bevat een steekproef van vijf knikkers vijf rode knikkers. De aanwezigheid van het kenmerk 'rood' wordt op basis van deze steekproef dus geschat op 100 procent. Een steekproef van acht knikkers bevat bij maximale vertekening vijf rode en drie gele knikkers. Op basis van een steekproef van acht knikkers is de geschatte aanwezigheid van 'rood' dus maximaal 63 procent. Bij een steekproef van negen knikkers is dit nog maximaal 56 procent, hetgeen de werkelijke (populatie)verdeling steeds dichter benadert.

6 Het rapport vermeldt abusievelijk een maximum van 5.400 leden bij een gemiddeld chapter van 40 leden.

$7 \quad$ Van der Heijden rekent in zijn voorbeeld enkel met de totale populatie en houdt geen rekening met het feit dat het aantal Hells Angels in de steekproef dichter bij het maximumaantal geschatte Hells Angels ligt, waardoor voor de Hells Angels het verschil in het percentage leden met een strafblad kleiner uitvalt. 
het rekenvoorbeeld ervan uit dat geen van de personen die lid is van een outlawmotorclub zonder dat dit bekend is bij de politie ooit is veroordeeld. Deze 'onbekende' outlawmotorclubleden zouden hiermee 'rechtschapener' zijn dan de gemiddelde Nederlandse man. In een eerder onderzoek gebruikten we een op leeftijd gematchte steekproef van mannelijke motorbezitters om het percentage veroordeelde outlawmotorclubleden in perspectief te plaatsen (Blokland e.a., 2017b). We vonden dat bijna een derde (32,3 procent) van de mannelijke motorrijders van middelbare leeftijd ten minste één keer in zijn leven was veroordeeld.

In figuur 2 op p. 255 zijn de gevolgen weergegeven van zowel de mate waarin de huidige steekproef de totale ledenpopulatie dekt, als het percentage veroordeelden onder leden die door de politie 'gemist' zouden kunnen zijn voor het geschatte percentage van alle outlawmotorclubleden (boven) en het geschatte percentage van alle Hells Angels (onder) dat ten minste één keer is veroordeeld. ${ }^{8}$

Figuur 2 laat zich als volgt lezen: de grijze onderbroken lijn geeft het percentage veroordeelde leden in de populatie wanneer we ervan uitgaan dat geen van de door de politie gemiste leden een strafblad heeft. De omvang van de huidige steekproef komt neer op een gemiddeld aantal van elf leden per chapter. Wanneer we de grijze onderbroken lijn volgen tot een gemiddeld aantal van 22 leden per chapter (oftewel een totale ledenpopulatie die twee keer groter is dan de huidige steekproef), resulteert dit in een percentage van 43,1 procent veroordeelde leden in de populatie. Wanneer we uitgaan van een (reëler) scenario waarbij de gemiste outlawmotorclubleden even vaak veroordeeld zijn als de gemiddelde mannelijke motorrijder (zwarte lijn), dan resulteert bij een twee keer grotere populatie een geschat veroordelingspercentage van 58,4 procent. Wanneer door de politie gemiste leden een twee keer zo grote kans hebben ooit te zijn veroordeeld als de gemiddelde motorrijder (witte lijn), dan komt het percentage veroordeelde outlawmotorclubleden in de totale populatie op 75,2 procent. Voor de volledigheid schetst de zwarte stippellijn het percentage veroordeelde leden in de populatie bij verschillende populatiegrootten wanneer de door de politie gemiste leden allemaal ooit zijn veroordeeld (bij een daadwerkelijke populatie van twee keer groter dan de huidige steekproef resulteert dan een percentage van 92,9 procent leden in de populatie met een strafblad).

Voor specifiek de Hells Angels geldt dat wanneer uitgegaan wordt van een gemiddeld aantal van 22 leden per chapter, schattingen van het percentage veroordeelde leden in de totale ledenpopulatie variëren van 65,2 procent (geen van de gemiste leden heeft een strafblad), via 71,6 procent (gemiste leden zijn even vaak veroordeeld als de gemiddelde motorrijder) tot 78,5 procent (gemiste leden zijn twee keer vaker veroordeeld dan de gemiddelde motorrijder). Wanneer wordt uitgegaan van het (extreme) gemiddelde van 40 leden per chapter en wordt aangenomen dat de gemiste leden niet crimineler zijn dan de gemiddelde motorrijder, dan zou naar schatting nog steeds meer dan de helft van de Hells Angels een strafblad hebben.

8 De scenarioschattingen met betrekking tot de volledige steekproef zijn ook opgenomen in Blokland e.a., 2019. 
Het klopt derhalve dat het gerapporteerde percentage veroordeelde leden (totaal en per club) gevoelig is voor selectiviteit in de steekproefsamenstelling, maar tegelijk kan worden vastgesteld dat zelfs onder de meest extreme scenario's het percentage 'ooit veroordeelden' onder de Hells Angels nog steeds hoger ligt dan dat onder volwassen mannelijke motorrijders in het algemeen en waarschijnlijker ergens ligt tussen de 71,6 en 92,0 procent. Voor de totale populatie ligt het daadwerkelijke percentage veroordeelde outlawmotorclubleden meest waarschijnlijk tussen 58,4 en 96,1 procent.

\section{Type 1-fouten: niet-leden onterecht geïdentificeerd als lid}

Het tweede punt van commentaar, ingegeven door de door Hells Angels aan Van der Heijden verstrekte gegevens, is dat de huidige steekproef het aantal Hells Angels-leden overschat. Er zou dan sprake zijn van type 1-fouten: personen die in werkelijkheid geen lid zijn, zouden desondanks als lid zijn geïdentificeerd. In de steekproef van het onderzoek is sprake van 319 personen die als lid van de Hells Angels zijn aangemerkt. Dit betekent dat zij ergens tussen 2010 en 2015 door een politieambtenaar zijn gezien (en geïdentificeerd) in clubkleding, met clubtatoeages of op besloten clubavonden. De Hells Angels claimen op dit moment echter 'ongeveer 250' Nederlandse leden te hebben. Hoewel onduidelijk blijft of dit aantal van 250 ook gold in de periode 2010 tot 2015 (wat overigens zou neerkomen op gemiddeld veertien leden per chapter) en hoe groot het eventuele verloop is geweest onder leden in die periode, kunnen we ook hier doorrekenen wat de gevolgen zijn van, in dit geval, een overschatting van de totale ledenpopulatie voor het gerapporteerde percentage leden met een strafblad. Wanneer de Hells Angels in de periode 2010-2015 inderdaad 250 leden hadden (en er geen verloop is geweest van leden in die periode), dan zouden 69 personen onterecht als lid van de Hells Angels zijn aangemerkt. Wanneer we er bovendien van uitgaan dat dit allemaal personen met een strafblad betreft, dan resteert een steekproef van 250 Hells Angels (de gehele populatie), van wie nog 191 (=260-69) ten minste één keer is veroordeeld. Na correctie voor mogelijke selectieve overschatting van de daadwerkelijke ledenpopulatie bedraagt het percentage Hells Angels met een strafblad derhalve minimaal 76,4 procent.

\section{Plaatsing op het club-bendecontinuüm}

Het derde punt van commentaar betreft de ordening zoals weergegeven in figuur 1. Van der Heijden merkt op dat door het gebruik van gemiddelden onduidelijk is hoeveel leden en leiders veroordeeld zijn voor 'georganiseerde criminaliteit', en bovendien de mogelijkheid bestaat dat deze gemiddelden worden vertekend door enkele leden die zeer vaak zijn veroordeeld voor dergelijke delicten. Dit betreft een terechte kanttekening bij een beslissing die overigens bewust is genomen. Om onthulling te voorkomen is ervoor gekozen de bellenplots (ooit veroordeelde leden/leiders (figuur 5.6, p. 108 Blokland, Van der Leest \& Soudijn, 2017) en ooit voor georganiseerde criminaliteit veroordeelde leden/leiders (figuur 5.7, p. 109 Blokland, Van der Leest \& Soudijn, 2017)) te baseren op gemiddelde aantallen 


\section{Totale steekproef}

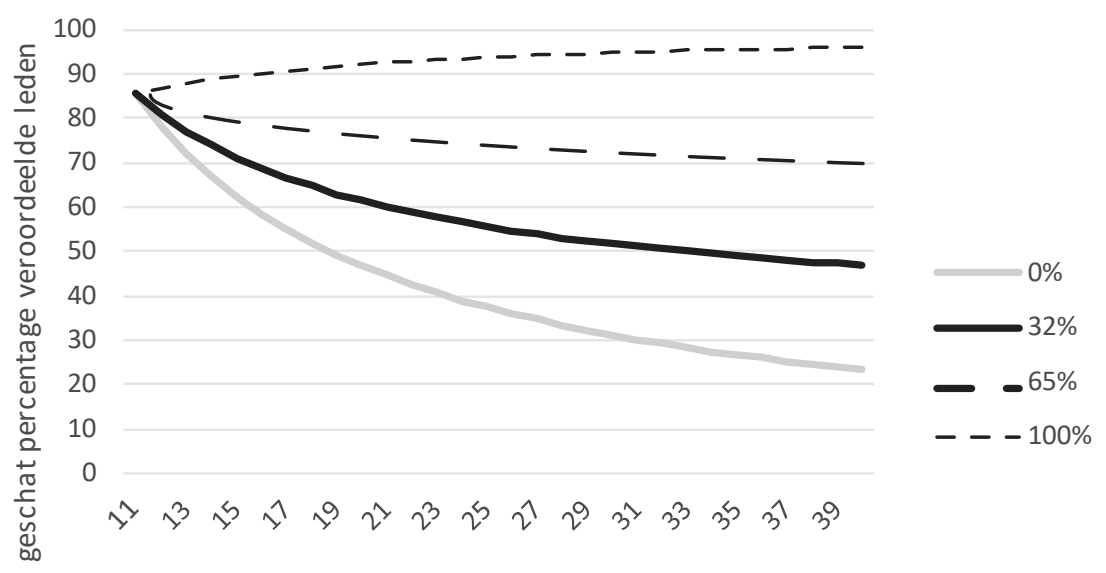

geschatte gemiddeld aantal leden per chapter

\section{Hells Angels}

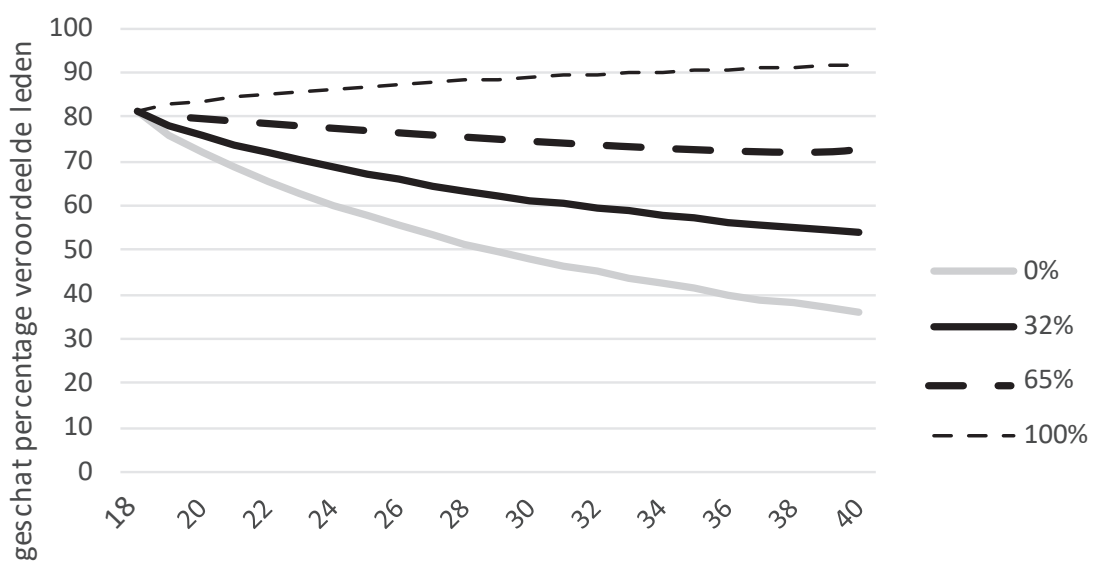

geschatte gemiddeld aantal leden per chapter

Figuur 2 Geschatte percentages veroordeelden in de totale ledenpopulatie onder verschillende vormen en mate van selectiviteit in de steekproef 
veroordelingen in plaats van percentages ten minste eenmaal veroordeelde leden/ leiders. ${ }^{9}$

Met 319 leden in de steekproef bestaat bij de Hells Angels echter geen gevaar voor onthulling en kunnen daarom aantallen leden en leiders en het percentage veroordeelde leden en leiders worden genoemd. Als 'leiders' worden die personen aangemerkt die, afgaand op de onderscheidingstekens die gedragen worden op hun vest, een speciale positie bekleden binnen de formele hiërarchie van de outlawmotorclub. Van de 319 Hells Angels in de steekproef worden 268 personen aangemerkt als 'lid' en 51 als 'leider'. Van de leden blijkt 81,9 procent ooit veroordeeld voor enig strafbaar feit. Gemiddeld hebben veroordeelde leden 8,9 eerdere veroordelingen op hun naam. Het totaalaantal veroordelingen van ooit veroordeelde leden varieert van 1 tot 42. Van de leiders heeft eveneens meer dan 80 procent een strafblad. Gemiddeld zijn veroordeelde leiders 9,2 keer veroordeeld voor enig strafbaar feit. Het totaalaantal veroordelingen van veroordeelde leiders varieert tussen de 1 en 31. De helft (50,6 procent) van de veroordeelde leden van de Nederlandse Hells Angels is ooit veroordeeld voor 'georganiseerde' criminaliteit. Een gemiddeld veroordeeld lid heeft 1,3 veroordelingen voor 'georganiseerde' criminaliteit op zijn strafblad. Van de veroordeelde leiders is 55,6 procent ooit veroordeeld voor 'georganiseerde' criminaliteit. Gemiddeld werden veroordeelde leiders 2,1 keer veroordeeld voor 'georganiseerde' criminaliteit. Ter illustratie: de percentages veroordeelde Hells Angels-leden en -leiders zijn vergelijkbaar met die van leden en leiders van Satudarah, wat, gegeven de positie die Satudarah inneemt in de bellenplot, betekent dat veroordeelde Satudarah-leiders gemiddeld minder veroordelingen voor 'georganiseerde' criminaliteit in hun veroordelingsgeschiedenis hebben dan veroordeelde leiders van de Hells Angels.

\section{Conclusie}

Woorden maken werelden en de manier waarop wij over zaken spreken, kleurt het beeld dat wij van deze zaken hebben. Voor cijfers geldt dit, vanwege hun vermeende objectiviteit, misschien nog wel sterker. Genoeg reden dus voor criminologen om, wanneer zij in hun onderzoek uitspraken doen over sociale fenomenen, voorzichtig te zijn in hun conclusies en de mitsen en maren die kleven aan hun onderzoek niet onder stoelen of banken te steken. De kritische blik van collegawetenschappers maakt een essentieel onderdeel uit van het wetenschappelijk proces dat uiteindelijk moet leiden tot meer en beter inzicht in de wereld waarin wij leven.

In dit geval richtte die kritische blik zich op mogelijke vertekening van resultaten uit het onderzoek naar de criminele carrières van Nederlandse outlawbikers als gevolg van een op registerdata gebaseerde steekproef. Dat bij het vullen van gangdatabases en doelgroepenbestanden zowel type 1- als type 2-fouten (kunnen) worden gemaakt, staat buiten kijf. Het uiterlijk vertoon van outlawbikers en de

9 Het CBS stelt dat sprake is van onthulling wanneer (a) gevoelige cellen meer dan 90 procent van de waarnemingen omvatten en/of (b) gevoelige cellen minder dan tien eenheden bevatten. 
door hen bedoeld zichtbaar gedragen onderscheidingstekens verkleinen in dit specifieke geval echter het risico op type 1-fouten, waarbij een persoon ten onrechte wordt aangemerkt als lid van een outlawbikerclub, aanzienlijk. Type 2fouten, waarbij bepaalde leden ten onrechte niet worden aangemerkt als lid, vormen derhalve potentieel de grootste bedreiging voor de getrokken conclusies.

In ons onderzoek beschikten we niet over beschrijvende gegevens met betrekking tot de totale populatie Nederlandse outlawbikers. Zowel de totale omvang als de precieze samenstelling van deze populatie is onbekend. We kunnen daarom geen uitspraken doen over de mate waarin de gebruikte steekproef statistisch representatief is voor alle outlawbikers in Nederland. Dit maakt dat conclusies getrokken op basis van gegevens over die steekproef alleen met een gepaste mate van voorzichtigheid kunnen worden geëxtrapoleerd naar de totale ledenpopulatie van Nederlandse outlawbikerclubs. Door middel van het doorrekenen van verschillende, meer en minder aannemelijke, scenario's hebben we in deze bijdrage inzichtelijk willen maken hoeveel voorzichtigheid in dit geval als 'gepast' kan worden beschouwd. De hier gepresenteerde resultaten vormen, ons inziens, geen reden om af te dingen op de oorspronkelijke conclusie van ons onderzoek, namelijk dat een aantal Nederlandse outlawbikerclubs, waaronder ook de Hells Angels, wordt gekenmerkt door een disproportioneel aantal leden dat vanwege het begaan van strafbare feiten in aanraking is gekomen met justitie.

Type 1- en type 2-fouten vormen niet alleen een bron van mogelijke vertekening in het onderzoek naar outlawbikers, maar in elk onderzoek dat beschrijvende resultaten presenteert van een niet volledig willekeurige steekproef en waarbij die resultaten expliciet of impliciet worden doorgetrokken naar de totale onderzoekspopulatie - door de onderzoekers zelf of door latere auteurs die naar de uitkomsten van dat onderzoek verwijzen. Dit geldt nog sterker wanneer het inclusiecriterium voor de betreffende steekproef niet gebaseerd is op relatief eenvoudig waar te nemen uiterlijke kenmerken - zoals het dragen van een bikervest - maar, zoals vaak het geval is in criminologisch onderzoek op basis van registerdata, op het al of niet geregistreerd zijn voor het plegen van een bepaald delict. Hoe groter het dark number voor het betreffende delict, hoe groter de mogelijke invloed van type 2 -fouten. Belangrijk is verder dat de mogelijke vertekening als gevolg van type 1 en type 2-fouten niet alleen betrekking heeft op de prevalentieschattingen van (bepaalde vormen van) criminaliteit in een populatie, maar ook andere criminelecarrièreparameters, zoals startleeftijd, frequentie, duur en criminaliteitsmix, raakt. Herhaald onderzoek op basis van verschillende databronnen (met elk een eigen, maar verschillende vorm en mate van vertekening) kan helpen om te komen tot een betrouwbaarder beeld.

In ons rapport werden Nederlandse bikerclubs, op basis van het gemiddeld aantal delicten voor leden en leiders, geordend langs het door Barker (2015; 2017) voorgestelde club-bendecontinuüm. Outlawbikerclubs waarvan leden en leiders een bovengemiddeld (ten opzichte van de andere clubs in de steekproef) aantal veroordelingen op hun naam hebben, werden geplaatst aan de 'bende'-kant van dit continuüm. Belangrijk is zich te realiseren dat de beide dimensies die samen het continuüm vormen, gebaseerd zijn op registraties van individueel gedrag. De gebruikte registerdata laten derhalve onbeantwoord in welke mate de geregis- 
treerde delicten gerelateerd zijn aan het clublidmaatschap, samen met andere leden zijn gepleegd, of door de clubleiding zijn geïnstigeerd. Er kan op basis van de beschikbare data met andere woorden geen onderscheid worden gemaakt tussen een vereniging van criminelen en een criminele onderneming (Von Lampe, 2016). Voor de juridische oordeelsvorming omtrent de 'werkzaamheid van de vereniging' leveren de huidige onderzoeksresultaten dan ook ten hoogste indirect bewijs. Vervolgonderzoek, bijvoorbeeld op basis van onderzoeksdossiers, waarbij meer aandacht kan worden besteed aan de aanleiding, organisatie en afwikkeling van de gepleegde delicten, zal meer duidelijkheid moeten verschaffen over de precieze rol van het clublidmaatschap - voor zover aanwezig - in het criminele gedrag van outlawbikers.

Tot slot nog dit. Woorden maken werelden en dit geldt evengoed voor de eenheid van analyse in doelgroepenonderzoek. Aandacht voor outlawbikerclubs impliceert dat clubgrenzen en organisatie relevant zijn voor het onderzochte gedrag. Onderzoek onder straatbendes leert echter dat dit niet altijd het geval hoeft te zijn; criminele samenwerkingsverbanden verlopen soms nauwelijks langs de lijnen van zelfgerapporteerde affiliatie met bepaalde straatbendes (McGloin, 2005). Internationaal onderzoek naar outlawbikerclubs liet reeds zien dat leden er ook veel criminele contacten buiten de club op na hielden (Morselli, 2009). In welke mate dit ook geldt voor Nederlandse outlawbikers en in welke mate geobserveerde dadernetwerken overlappen met de formele outlawbikerstructuur van clubs, chapters en de verschillende rangen hierbinnen is op dit moment onduidelijk. Ook hier kan echter toekomstig onderzoek uitkomst bieden.

Op 29 mei 2019 oordeelt de Rechtbank Midden-Nederland dat binnen de Hells Angels sprake is van een geweldscultuur die zo kenmerkend en structureel is dat de werkzaamheid van de vereniging in strijd is met de openbare orde, en verbiedt zij de Hells Angels MC. Bij monde van hun advocaat hebben de Hells Angels inmiddels aangekondigd in hoger beroep te gaan tegen dit vonnis.

\section{Literatuur}

Barker, T. (2015). Biker gangs and transnational organized crime. Newark, NJ: Anderson Publishing.

Barker, T. (2017). Motorcycle clubs or criminal gangs on wheels? In: A. Bain \& M. Lauchs (eds.). Understanding the outlaw motorcycle gangs: international perspectives. Durham, NC: Carolina Academic Press, 3-27.

Barrows, J. \& Huff, C.R. (2009). Constructing and deconstructing gang databases. Criminology \& Public Policy, 8(4), 675-703.

Blokland, A., Leest, W. van der \& Soudijn, M. (2017a). Profielen van Nederlandse outlawbikers en Nederlandse outlawbikerclubs. Apeldoorn: Politie \& Wetenschap.

Blokland, A., Leest W. van der \& Soudijn, M. (2019). Officially registered criminal careers of members of Dutch outlaw motorcycle gangs and their support clubs. Deviant Behavior. doi:10.1080/01639625.2019.1619422. 
Blokland, A., Hout, L. van, Leest, W. van der \& Soudijn, M. (2017b). Not your average biker. Criminal careers of members of Dutch outlaw motorcycle gangs. Trends in Organized Crime. doi:10.1007/s12117-017-9303-x.

Finckenauer, J.O. (2005). Problems of definition: what is organized crime? Trends in Organized Crime, 8 (3), 63-83.

McGloin, J.M. (2005). Policy intervention considerations of a network analysis of street gangs. Criminology \& Public Policy, 4, 607-635.

Morselli, C. (2009). Inside criminal networks. New York: Springer.

Roks, R.A. \& Ruitenburg, T. van (2018). Dutch gang talk. A reflection on the use of the gang label in the Netherlands. In: T. Kuldova \& M. Sánchez-Jankowski (eds.). Outlaw motorcycle clubs and street gangs. Cham, Switzerland: Palgrave Macmillan, 69-91.

Von Lampe, K. (2016). Organized crime. Analyzing illegal activities, criminal structures, and extra-legal governance. Los Angeles, CA: Sage. 